\title{
Biological control of Meloidogyne javanica in bean plants by Hohenbuehelia spp. and Trichoderma koningiopsis
}

\author{
Cleonice Lubian 1,2,* (D) https://orcid.org/0000-0003-3419-6710 \\ Odair José Kuhn¹ (D) https://orcid.org/0000-0002-6803-4579 \\ Roberto Luis Portz ${ }^{2}$ (D) https://orcid.org/0000-0002-1568-7330

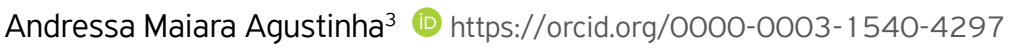 \\ José Renato Stangarlin¹ (iD https://orcid.org/0000-0001-8601-9439 \\ 1. Universidade Estadual do Oeste do Paraná - Campus Marechal Cândido Rondon - Laboratório de Fitopatologia - Marechal \\ Cândido Rondon (PR), Brazil. \\ 2. Universidade Federal do Paraná - Setor Palotina - Laboratório de Fitopatologia - Palotina (PR), Brazil. \\ 3. Universidade Federal do Paraná - Setor Palotina - Programa de Pós-graduação em Aquicultura e Desenvolvimento Sustentável - \\ Palotina (PR), Brazil. \\ ${ }^{*}$ Corresponding author: cleo.lubian@gmail.com
}

\begin{abstract}
Nematode control strategies are limited and alternative control is demanded. The main aim was to evaluate control potential of Hohenbuehelia spp. (Hohenbuehelia mastrucata, Hohenbuehelia barbatula, Hohenbuehelia bullulifera, Hohenbuehelia portegna, Hohenbuehelia petaloides and Hohenbuehelia paraguayensis) and Trichoderma koningiopsis against Meloidogyne javanica in bean plants in greenhouse. The parameters evaluated were the number of galls and egg masses which were evaluated in three root regions: basal, intermediate and tip; nematode reproduction factor; vegetal growth parameters (plants height on V1, V2, V4, and R5 growth stages, root length, dry weight of root and aerial part dry weight); Treatments were composed by individual interactions of each fungal isolate with 4,000 eggs of M. javanica, having a total control (bean) and a partial control (bean + nematode) arranged in completely randomized design with four repetitions. Data were tested by Scott-Knott (5\%). For vegetal growth parameters, there was only significance for dry weight of roots. All species were able to control nematodes.
\end{abstract}

Keywords: nematodes. alternative control. anamorphic. phytopathology.

\section{INTRODUCTION}

Meloidogyne genus, known as root gall nematode, covers polyphagous species spread all over the soils and adapted to Brazilian regions (MACHADO, 2014). There are over 90 species, especially Meloidogyne arenaria, Meloidogyne incognita, Meloidogyne javanica, and Meloidogyne hapla (FERRAZ, 2018).

Galls are direct symptoms of Meloidogyne attack, apart from some cases (FERRAZ; BROWN, 2016). Galls are an expression of a feeding site, the cenocyte, a metabolic drain essential to nematode development (FERRAZ, 2018). Therefore, nematode attack leads to cenocyte formation with eventual, although frequent, galls. Galls may occur early in female maturity (FERRAZ; BROWN, 2016).

As female maturity goes, there is an average deposition of 400 exposed eggs (FERRAZ, 2018), representing the reproductive cycle conclusion. Egg masses counting is studied in many pathosystems for reproduction analysis of Meloidogyne spp., as well as to evaluate the reaction of commercial crops (ROSA et al., 2013; CHAVES et al., 2013). No doubt egg masses are much more relevant to consider for epidemiological parameters than galls, besides galls are not an exclusivity of Meloidogyne genus (BEDENDO, 2018).

There are several means to control nematodes, classified as chemical, physical, cultural, genetic and biological. Some methods have wider applications while others cannot be applied in some cases. Whenever possible, it is preferred to opt for integrated management (AL-HAZMI; TARIQJAVEED, 2016).

Biological control implies in the use of antagonist microorganisms in the infection site, before or after its occurrence (AGRIOS, 2005), as an important tool to substitute chemical appliance (MORANDI; BETTIOL, 2009). 
Fungi represent the group with the most interesting characteristics to control nematodes, as parasitism (FERRAZ; SANTOS, 1995), enzymes liberation and production of toxic metabolites (MORGAN-JONES; RODRÍGUEZ-KÁBANA, 1985). That means diversified abilities to catch nematodes at any life cycle stage, from eggs to adults (LIU et al., 2009). For that to occur, satisfactory mycelial growth is required to keep fungal in soil (FERRAZ et al., 2010).

Little is known about Hohenbuehelia genus in in vivo essays, only from PUTZKE et al. (2007). In vitro analysis of THORN; BARRON (1984) covered 108 species of Hohenbuehelia, from which Hohenbuehelia atrocaerulea, Hohenbuehelia paraguayensis, Hohenbuehelia portegna, Hohenbuehelia petaloides, Hohenbuehelia mastrucata and Hohenbuehelia grisea are endoparasites with nematophagous ability. LUBIAN et al. (2018) verified nematophagous ability for $H$. mastrucata, $H$. paraguayensis and $H$. portegna against Panagrellus redivivus.

The main goal was to verify nematophagous potential of $H$. mastrucata, H. barbatula, H. bullulifera, H. paraguayensis, $H$. portegna, $H$. petaloides and Trichoderma koningiopsis against $M$. javanica, in bean plants in greenhouse.

\section{MATERIALS AND METHODS}

The following isolates were tested: 436 - H. mastrucata, 461 - H. barbatula, 528 - H. bullulifera, 581 - H. paraguayensis, 631 - H. portegna, $H$. petaloides and TLB17 T. koningiopsis, all were recovered from Castellani technique.

Symptomatic okra roots were submitted to the nematode extraction process, according to JENKINS (1964). The specie was analyzed and identified as M. javanica (CHITWOOD, 1949). Nematodes number was calibrated in Peter Chamber at 4,000 eggs/J2 for inoculation. Eggs were added in soil five days after seedling transplant.

\section{In vitro colonization of Hohenbuehelia spp. (preliminary test)}

The matrix colony of each isolate, 436, 461, 528, 581, 631 and $H$. petaloides was growing on malt extract agar (MEA) from which 10 agar plugs ( $3 \mathrm{~mm}$ diameter) were removed and transferred to the center of new Petri plates containing MEA, for recolonization and purification. The plates were then sealed with parafilm and stored into bio-oxygen demand (BOD) chamber at $23.3^{\circ} \mathrm{C}$, without light. Each treatment had five repetitions disposed in a completely random design.

The new colonies were evaluated for mycelial growth efficiency (speed and extent). Two measures ( $\mathrm{cm}$ ) were taken from diametrically opposite directions. Evaluations occurred every other five days during six weeks. Data were run by Tukey's test at 5\% error probability using SISVAR 5.6 program (FERREIRA, 2011).

The inocula preparation process considered the mycelia grown in MEA from which 10 plugs $(8 \mathrm{~mm}$ diameter) were taken and added into a beaker containing $42 \mathrm{~g}$ of sterile rice $\left(2 \mathrm{~h}, 120^{\circ} \mathrm{C}, 1 \mathrm{~atm}\right)$ for the individual colonization of all above-mentioned isolates. The beaker was sealed with aluminum paper and kept into BOD at $25^{\circ} \mathrm{C}$.

\section{Bean seed germination test and seedling colonization}

Bean seeds (cultivar IPR Uirapuru), kindly given by IAPAR Institute, were submitted to germination test in accordance to the Seed Analysis Rules (BRAZIL, 2009).

To guarantee root colonization, each bean seed was sowed $2 \mathrm{~cm}$ deep together with three rice grains fully colonized (quantity set from preliminary test) in trays containing commercial substrate.

\section{Meloidogyne javanica control by fungi isolates and growth promotion in bean plants}

The species $H$. mastrucata, $H$. portegna, $H$. petaloides, $H$. paraguayensis and $T$. koningiopsis previously purified on MEA and grown in sterile rice grains were added in trays in the first place, being separated from bean seeds by a thin layer of substrate. Passed 13 days from emergence, seedlings were transplanted to $3 \mathrm{~L}$ vases (one seedling per vase). Vases were covered with hay autoclaved for two hours $\left(120^{\circ} \mathrm{C}, 1 \mathrm{~atm}\right)$.

The vases were filled with eutroferric red latosol soil (SANTOS et al., 2018) and sand (2:1, respectively), besides $45 \mathrm{~g}$ of sawdust. Around 10 soil samples were randomly taken from vases and turned into a composed soil sample which was submitted to chemical analysis and interpretation, being fertilized accordingly.

The experiment was set in a completely random design with five repetitions conducted in a greenhouse. The treatments were labeled as: T1 - M. javanica + H. mastrucata; T2 - M. javanica + H. paraguayensis; T3 - M. javanica + H. portegna; T4-M. javanica + 
H. petaloides; T5 - M. javanica + T. koningiopsis; T6 - partial control with only M. javanica and T7 - absolute control without treatment and pathogen.

For growth promotion, plants height at V1, V3, V4, and R7 stages were measured. Root evaluations were done 82 days after nematodes inoculation, at R8 stage, considering egg masses and galls counting, dry weight of roots, dry weight of the aerial part and root length.

Roots were detached from the aerial part in the greenhouse, packed and identified. In laboratory, they were submitted to triple washing in water, dried in absorbent paper and placed into dye solution ( $1 \mathrm{~mL}$ fuchsine $+30 \mathrm{~mL}$ distilled water) for $60 \mathrm{~min}$ to get egg masses exposition. Regarding to the counting, each root was separated into three different parts: basal, intermediate and the extremity. Hence, fragments of the respective parts were analyzed using magnifying eyes $(4 \times)$. Roots were entirely analyzed. Afterwards, dry roots were weighted and submitted to nematode extraction (JENKINS, 1964). Eggs were counted in Peters chamber and used to set the reproduction factor of $M$. javanica, in accordance to the methodology of FERRAZ (1996).

Temperature and humidity readings were taken daily using a thermohygrometer.

For statistics, data were analyzed by Scott-Knott test at $5 \%$ of error probability through SISVAR 5.6 program (FERREIRA, 2011).

\section{RESULTS}

The best mycelial growth was set for $H$. barbatula and $H$. mastrucata which, in seven days, reached $9.0 \mathrm{~cm}$ (full plate), followed by $H$. petaloides with $3.07 \mathrm{~cm}$. The other species did not reach over $1.0 \mathrm{~cm}$ of growth in seven days (Table 1).

Table 1. Diameter of mycelial growth $(\mathrm{cm})$ of Hohenbuehelia species cultivated in Malt Extract Agar stored into $\mathrm{BOD}$ at $25^{\circ} \mathrm{C}$ for 42 days.

\begin{tabular}{lcccccc}
\hline Species & $\mathbf{7}$ days & $\mathbf{1 4}$ days & $\mathbf{2 1}$ days & $\mathbf{2 8}$ days & $\mathbf{3 5}$ days & $\mathbf{4 2}$ days \\
\hline H. barbatula & $9.00 \mathrm{e}$ & $9.00 \mathrm{e}$ & $9.00 \mathrm{~d}$ & $9.00 \mathrm{~d}$ & $9.00 \mathrm{~d}$ & $9.00 \mathrm{e}$ \\
\hline H. bullulifera & $9.00 \mathrm{a}$ & $0.84 \mathrm{a}$ & $1.48 \mathrm{a}$ & $2.16 \mathrm{a}$ & $2.67 \mathrm{a}$ & $3.47 \mathrm{~b}$ \\
\hline H. mastrucata & $9.00 \mathrm{e}$ & $9.00 \mathrm{e}$ & $9.00 \mathrm{~d}$ & $9.00 \mathrm{~d}$ & $9.00 \mathrm{~d}$ & $9.00 \mathrm{e}$ \\
\hline H. petaloides & $3.07 \mathrm{~d}$ & $4.71 \mathrm{~d}$ & $5.54 \mathrm{c}$ & $5.89 \mathrm{c}$ & $6.08 \mathrm{c}$ & $6.7 \mathrm{~d}$ \\
\hline H. portegna & $0.91 \mathrm{c}$ & $1.34 \mathrm{c}$ & $2.35 \mathrm{~b}$ & $9.09 \mathrm{~b}$ & $3.85 \mathrm{~b}$ & $4.44 \mathrm{c}$ \\
\hline H. paraguayensis & $0.74 \mathrm{~b}$ & $1.08 \mathrm{~b}$ & $1.58 \mathrm{a}$ & $1.95 \mathrm{a}$ & $2.24 \mathrm{a}$ & $2.41 \mathrm{a}$ \\
\hline C.V. $(\%)$ & 3.27 & 4.84 & 6.07 & 7.68 & 10.14 & 12.8 \\
\hline General Media & 4.54 & 4.33 & 4.83 & 6.18 & 5.47 & 5.84 \\
\hline
\end{tabular}

* Means followed by the same letter in the same column did not differ significantly from each other by Tukey's test at $5 \%$ of probability.

As soon the vegetative development of the species was known the experiment schedule was properly set, having the inocula in the required quantity in young age according to the condition of each specie, such as growth speed.

The species $H$. mastrucata, $H$. paraguayensis and $H$. portegna had higher values for root expansion, although did not differ from the treatment inoculated with $M$. javanica (Table 2), this last due to the excess of galls formation (Table 3 ).

Table 2. Influence of the treatments on dry weight of bean roots (DMR).

\begin{tabular}{ll}
\hline Treatments & DMR \\
\hline Absolute control & $0.35 \mathrm{a}$ \\
\hline H. mastrucata & $0.55 \mathrm{~b}$ \\
\hline H. paraguayensis & $0.59 \mathrm{~b}$ \\
\hline H. petaloides & $0.26 \mathrm{a}$ \\
\hline H. portegna & $0.45 \mathrm{~b}$ \\
\hline T. koningiopsis & $0.25 \mathrm{a}$ \\
\hline Partial control & $0.54 \mathrm{~b}$ \\
\hline C.V. (\%) & 38.35 \\
\hline General Media & 0.43 \\
\hline
\end{tabular}

* Means followed by the same letter in the same column did not differ significantly from each other by Tukey's test at $5 \%$ of probability. 
Table 3. Counting of galls from the base (GB), intermediate (GI), extremity part of root (GE) and total galls (TG) for each treatment with the respective reduction indexes for each part of the root, compared to the partial control (nematode).

\begin{tabular}{lccccccc}
\hline Treatments & GB & Reduction (\%) & GI & Reduction (\%) & GE & TG & Reduction (\%) \\
\hline Absolute control & $0.00 \mathrm{a}$ & $*$ & $0.00 \mathrm{a}$ & $*$ & $0.00 \mathrm{a}$ & $0.00 \mathrm{a}$ & $*$ \\
\hline H. mastrucata & $51.33 \mathrm{a}$ & $\downarrow 86.72$ & $23.33 \mathrm{a}$ & $\downarrow 71.07$ & $10.00 \mathrm{a}$ & $84.66 \mathrm{a}$ & $\downarrow 81.42$ \\
\hline H. paraguayensis & $54.00 \mathrm{a}$ & $\downarrow 86.03$ & $26.33 \mathrm{a}$ & $\downarrow 67.36$ & $19.00 \mathrm{a}$ & $99.33 \mathrm{a}$ & $\downarrow 78.20$ \\
\hline H. petaloides & $97.00 \mathrm{a}$ & $\downarrow 74.91$ & $27.00 \mathrm{a}$ & $\downarrow 66.53$ & $6.66 \mathrm{a}$ & $130.66 \mathrm{a}$ & $\downarrow 71.32$ \\
\hline H. portegna & $79.33 \mathrm{a}$ & $\downarrow 79.48$ & $34.00 \mathrm{a}$ & $\downarrow 57.84$ & $19.66 \mathrm{a}$ & $126.33 \mathrm{a}$ & $\downarrow 72.27$ \\
\hline T. koningiopsis & $287.00 \mathrm{~b}$ & $\downarrow 25.77$ & $72.66 \mathrm{~b}$ & & $11.66 \mathrm{a}$ & $309.00 \mathrm{~b}$ & $\downarrow 32.18$ \\
\hline Partial control & $386.67 \mathrm{c}$ & & $80.66 \mathrm{~b}$ & & $29.66 \mathrm{a}$ & $455.66 \mathrm{c}$ & \\
\hline C.V. (\%) & 26.38 & & 81.07 & & 79.72 & 41.51 &
\end{tabular}

* Means followed by the same letter in the same column did not differ significantly from each other by Tukey's test at $5 \%$ of probability.

Plants heights measured at V1, V3, V4, and R5 stages did not differ among treatments, it is to say that none of them promoted plant growth. Also, there was no difference for the dry weight of the aerial part and root length.

Treatments differed for the counting of basal galls, intermediate galls and total galls (Table 3). Analyses of galls in the extremity of the roots ended up with no difference, suggesting that fungal colonization varied significantly, possibly due to the lower aeration as depth goes or due to the shorter time fungi had to get established in roots before nematode inoculation.

Data showed great ability of Hohenbuehelia species to reduce galls formation of M. javanica in bean roots, followed by T. koningiopsis. This last was only efficient to the basal roots.

Fungal activity over egg masses reduction had a similar tendency with relevance only for egg masses on basal part and total egg masses (Table 4). The best reduction percentuals in the basal part of the root were reached by H. mastrucata, $H$. portegna and $H$. petaloides at rates of $74.80,70.68$ and $65.41 \%$, respectively.

Table 4. Counting of egg masses from the base (EMB), intermediate (EMI), extremity part of root (EME) and total egg masses (TEM) for each treatment with the respective reduction indexes for each part of the root compared to the partial control (nematode).

\begin{tabular}{lcccccccc}
\hline Treatments & EMB & Reduction (\%) & EMI & EME & TEM & Reduction (\%) & Reduction (\%) \\
\hline Absolute control & O.00a & $*$ & $0.00 \mathrm{a}$ & 0.00a & 0.00a & $*$ & $*$ \\
\hline H. mastrucata & $137.5 \mathrm{Ob}$ & $\downarrow 74.80$ & $61.75 \mathrm{a}$ & $36.00 \mathrm{a}$ & $235.25 \mathrm{~b}$ & $\downarrow 66.39$ & $\downarrow 81.42$ \\
\hline H. paraguayensis & $329.75 \mathrm{c}$ & $\downarrow 39.56$ & $81.25 \mathrm{a}$ & $39.75 \mathrm{a}$ & $450.75 \mathrm{c}$ & $\downarrow 35.60$ & $\downarrow 78.20$ \\
\hline H. petaloides & $188.75 \mathrm{~b}$ & $\downarrow 65.41$ & $77.50 \mathrm{a}$ & $14.75 \mathrm{a}$ & $281.00 \mathrm{~b}$ & $\downarrow 59.85$ & $\downarrow 71.32$ \\
\hline H. portegna & $160.00 \mathrm{~b}$ & $\downarrow 70.68$ & $68.25 \mathrm{a}$ & $48.50 \mathrm{a}$ & $276.75 \mathrm{~b}$ & $\downarrow 60.46$ & $\downarrow 72.27$ \\
\hline T. koningiopsis & $278.50 \mathrm{c}$ & $\downarrow 48.96$ & $66.00 \mathrm{a}$ & $14.75 \mathrm{a}$ & $359.25 \mathrm{~b}$ & $\downarrow 48.68$ & $\downarrow 32.18$ \\
\hline Partial control & $545.75 \mathrm{~d}$ & & $110.75 \mathrm{a}$ & $43.50 \mathrm{a}$ & $700.00 \mathrm{~d}$ & & & \\
\hline C.V. (\%) & 44.06 & & 90.92 & 109.01 & 45.91 & & & \\
\hline General Media & 234.32 & & 66.50 & 28.18 & 329.00 & & &
\end{tabular}

* Means followed by the same letter in the same column did not differ significantly from each other by Tukey's test at $5 \%$ of probability.

Figure 1 indicates that galls quantity is not proportional to egg masses quantity once there were galls without egg mass formation (A), one egg mass per gall as well as four egg masses per gall (B) and finally a huge gall from basal part containing over 10 galls $(\mathrm{C})$.

Related to the eggs number extracted from the roots, it is seen that the best treatment was H. mastrucata alike the absolute control outcome (Table 5). In sequence, the species $H$. paraguayensis, $H$. petaloides and $H$. portegna stood out. A third level was formed by T. koningiopsis. Finally, the treatment containing only nematodes, showed the highest eggs number and, consequently, the highest reproduction factor, as expected.

Root dry weight results did not have relation with the performance of the treatments to control nematodes, especially for H. petaloides (Table 2). 

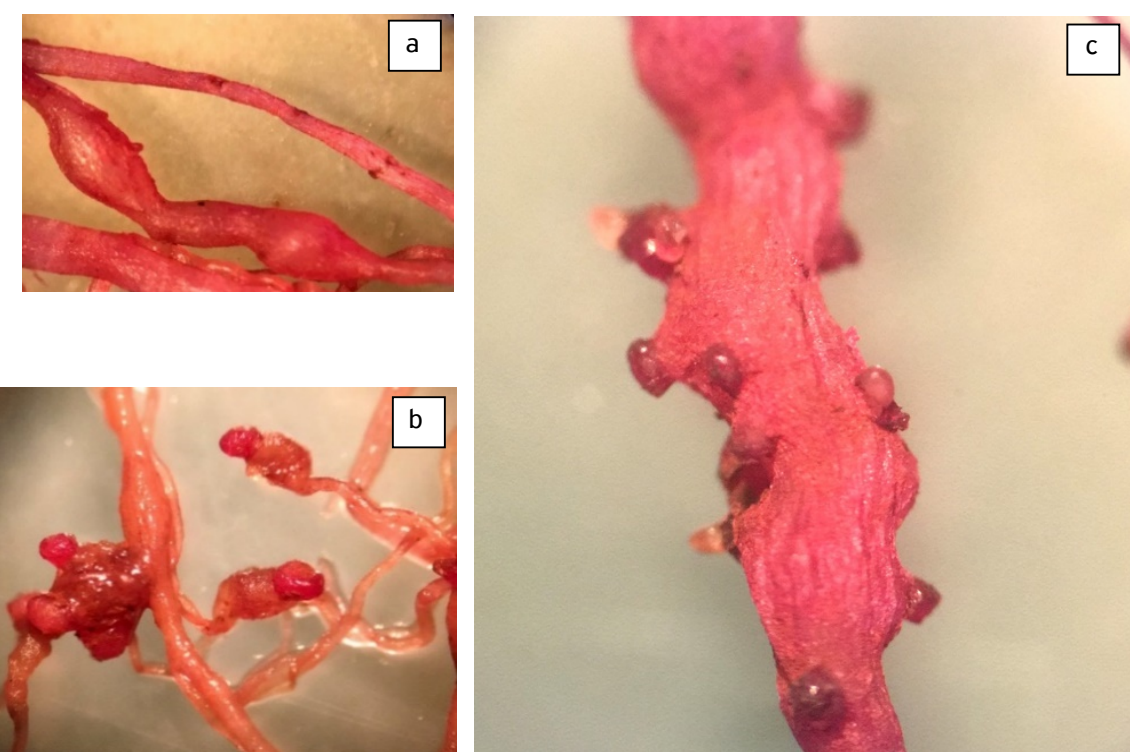

Figure 1. Indirect relation between galls and egg masses of $M$. javanica in bean roots. $a=$ galls without egg masses. $b=$ two galls with one egg mass each and one gall containing four egg masses. $c=$ one big gall with 10 visible egg masses.

Table 5. Eggs number, reproduction factor (RF) of $M$. javanica and reduction percentual of eggs by each treatment compared to the partial control (nematode).

\begin{tabular}{lccc}
\hline Treatments & Eggs number & RF & Reduction (\%) \\
\hline Absolute control & $0.00 \mathrm{a}$ & $*$ & $\downarrow$ \\
\hline H. mastrucata & $1644.50 \mathrm{a}$ & 0.41 & $\downarrow 84.86$ \\
\hline H. paraguayensis & $3845.36 \mathrm{~b}$ & 0.96 & $\downarrow 64.60$ \\
\hline H. petaloides & $4103.46 \mathrm{~b}$ & 1.03 & $\downarrow 62.22$ \\
\hline H. portegna & $3021.63 \mathrm{~b}$ & 0.76 & $\downarrow 72.18$ \\
\hline T. koningiopsis & $5900.99 \mathrm{c}$ & 1.48 & $\downarrow 45.67$ \\
\hline Partial control & $10862.20 \mathrm{~d}$ & 2.72 & \\
\hline C.V. $(\%)$ & 39.64 & 0.66 & \\
\hline General Media & 4896.36 & 1.23 & \\
\hline
\end{tabular}

* Means followed by the same letter in the same column did not differ significantly from each other by Tukey's test at $5 \%$ of probability.

\section{DISCUSSION}

According to FERRAZ et al. (2010), an abundant mycelial growth is required for fungal introduction in soil for biological control to succeed. However, in vitro analysis showed no relation between mycelial growth of Hohenbuehelia species and their control over nematodes (THORN; BARRON, 1986; LUBIAN et al., 2018). The present work also confirms this nonrelation once the general effect of the treatments (Tables 3 and 4 ) had no direct relation to the mycelial growth, having $H$. portegna as an example (Table 1).

Dry weight of the aerial part was not affected by any treatment (data not shown). However, some stimuli on bean was expected, especially due to reports related to Trichoderma species. In the same way, there was no promotion on bean growth (SANTIN, 2008; AGUIAR et al., 2014). PUTZKE et al. (2007) verified reduction on fresh matter of tomatoes treated with $H$. paraguayensis compared to H. portegna.

Researches on biocontrol of nematodes generally consider the introduction of the antagonist agent before transplanting the plant host (DALLEMOLE-GIARETTA et al., 2008; AL-HAZMI; TARIQJAVEED, 2016), resulting in a longer interaction to reduce nematode inoculum. It is an advantage for ovicidal antagonists, such as Trichoderma (SZABÓ et al., 2012) and Pochonia chlamydosporia (NUNES et al., 2010). In this study, fungi were added during sowing, having 19 days to establish in the substrate and roots before the addition of $M$. javanica.

About the galls, SANTIN (2008) reported less expression in bean treated with Trichoderma harzianum, while SHARON et al. (2001) verified an index of 0.5 galls in tomato treated with a savage isolate of T. harzianum. Also, T. koningiopsis presented the ability to reduce galls formation (Table 3). Related to this, VINALE et al. (2008) cites the existence of Trichoderma strains with distinct effectiveness. Likewise, AL-HAZMI; TARIQJAVEED (2016) checked different performances among species, justified by pathogenic ability of the isolates or their origin. 
In respect of galls formation and the occurrence of eggs and juveniles in bean roots, BORGES et al. (2013) checked similar results for the control treatment inoculated with $M$. incognita only and for plants treated with Trichoderma sp. In fact, T. koningiopsis did not present the best role to reduce galls formation in bean roots (Table 3) but it differed from the treatment inoculated with M. javanica, at least.

By analyzing the reduction percentual of galls and egg masses of $M$. javanica (Tables 3 and 4), it was verified that $H$. mastrucata, $H$. portegna and $H$. petaloides presented control potential superior to many commercial products of antagonists, such as Rizotec in cucumber (VIGGIANO et al., 2014), Rizotec and Onix SC + Quality WG in tomato (CARVALHO, 2017), Nemix TS in soybean (NUNES et al., 2010), Trichodermil SC 1306 and Quality in bean (AGUIAR et al., 2014), revealing the potential for commercial use, especially remembering that these results were obtained with low dosage of inocula.

In the pathosystem M. incognita $\times$ lettuce, MARINO; SILVA (2013) confirmed the efficiency of four isolates of Pleurotus osteatrus, a genus belonging to the same family as Hohenbuehelia. According to them, all isolates reduced galls and egg masses indexes compared to the control, ranging from 74 to $89 \%$ for galls number and from 87 to $98 \%$ for egg masses formation. Their results are very similar to Hohenbuehelia spp. performance, which varied from 74.9 to $86.72 \%$ for galls and from 39 to $74.8 \%$ for egg masses, except for $H$. paraguayensis for both parameters.

Table 5 reveals that a high reduction in galls does not imply necessarily in the same reduction for egg masses, having H. paraguayensis as an example. Egg masses have an undeniable impact on epidemiology once they lead to higher nematode population for the next cycles (MARINO; SILVA, 2013). PIRES et al. (2016) also testified the same situation expressed in Figure 1 in bean plants infected by M javanica. According to them, the cultivars which presented higher galls number were not the same that expressed higher number of egg masses.

On the other hand, no matter what crop or biocontrol agent it is, there is a strong relation between egg masses number and galls expression (LOPES et al., 2007; PUTZKE et al., 2007; SANTIN, 2008; DALLEMOLE-GIARETTA et al., 2008; NUNES et al., 2010; MACHADO et al., 2013; PINHEIRO et al., 2013).

Reproduction factor (RF) is about the relation of final and initial population of nematodes, indicating their reproduction index throughout the growing stages of a given plant specie. FERRAZ (1996) adapted a scale of RF indexes to set reductions varying from 0 to $25 \%$ which classifies a cultivar as highly susceptible, from 26 to $50 \%$ as susceptible, from 51 to $95 \%$ as quite resistant and over $95 \%$ as resistant. In this context, the bean treated with T. koningiopsis ended up in a susceptible reaction, while the bean plants treated with Hohenbuehelia species were quite resistant. The treatment of M. javanica expressed the highest index of nematode reproduction (Table 5).

Results suggest that Hohenbuehelia species have a quick action over nematodes whose fast control has been already identified by LUBIAN et al. (2018).

\title{
CONCLUSION
}

All species tested presented biological control potential against Meloidogyne javanica in bean plants at some extent.

\begin{abstract}
AUTHORS' CONTRIBUTIONS
Conceptualization: Stangarlin, J.R. Data curation: Lubian, C. Formal analysis: Agustinha, A.M. Investigation: Lubian, C. Methodology: Portz, R.L. Supervision: Kuhn, O.J. Writing - original draft and Writing - review \& editing: Lubian, C.
\end{abstract}

AVAILABILITY OF DATA AND MATERIAL

All data generated or analyzed during this study are included in this published article.

FUNDING

Not applicable.

CONFLICTS OF INTEREST

The authors certify that they have no commercial or associative interest that represents a conflict of interest in connection with the manuscript.

ETHICAL APPROVAL

Not applicable.

The authors would like to thank Instituto Agronômico do Paraná (IAPAR) for the gentle sharing of the bean seeds. 


\section{REFERENCES}

AGRIOS, G.N. Plant diseases caused by nematodes. In: Plant pathology. San Diego: Academic Press, 2005. chap.15, p.826-848.

AGUIAR, P.E.V.; BONALDO, S.M.; MORAES, S.R.G. Evaluation of Trichoderma spp. on bean culture, in anthracnose, web blight and root-knot nematode. Scientific Electronic Archives, Rondonópolis, v.7, p.17-25, 2014. Available from: http://sea.ufr.edu.br/index.php?jo urnal $=$ SEA \&page $=$ article\&op $=$ view\&path\%5B\%5=106. Access on: 28 Aug. 2017.

AL-HAZMI, A.S.; TARIQJAVEED, M. Effects of different inoculum densities of Trichoderma harzianum and Trichoderma viridae against Meloidogyne javanica on tomato. Saudi Journal of Biological Sciences, Riyadh, v.23, n.2, p.288-292, 2016. https://doi.org/10.1016/j. sjbs.2015.04.007

BEDENDO, I.P. Galhas. In: AMORIM, L.; REZENDE, J.A.M.; BERGAMIN FILHO, A. Manual de Fitopatologia: princípios e conceitos. Ouro Fino: Agronômica Ceres, 2018. chap.31, p.365-368.

BORGES, F.G.; BATISTTUS, A.G.; MULlER, M.A.; MIORANZA, T.M.; KUHN, O.J. Manejo alternativo de nematoides de galha (Meloidogyne incognita) em feijoeiro (Phaseolus vulgaris). Scientia Agraria Paranaensis, Marechal Cândido Rondon, v.12, suplemento, p.425-433, 2013. Available from: http://e-revista.unioeste.br/index.php/scientiaagraria/article/view/9573. Access on: 28 Nov. 2018.

BRAZIL. Ministério da Agricultura, Pecuária e Abastecimento. Teste de germinação. In: Regras para análise de sementes. Brasília: Mapa/ ACS, 2009. chap.5, p.147-224. Available from: https://www.gov.br/agricultura/pt-br/assuntos/insumos-agropecuarios/arquivos-publicacoesinsumos/2946_regras_analise_sementes.pdf. Access on: 28 Oct. 2018.

CARVALHO, P.H. Controle biológico e alternativo de Meloidogyne incognita e M. javanica em tomateiro. 2017. 98f. Dissertation (Masters in Phytopathology) - Universidade de Brasília, Brasília, 2017. Available from: https://repositorio.unb.br/bitstream/10482/23402/1/2017_ Patr\%C3\%ADciaHonoratodeCarvalho.pdf. Access on: 10 Oct. 2018.

CHAVES, P.P.N.; SANTOS, G.R.; SILVEIRA, M.A.; GOMES, L.A.A.; MOMENTÉ, V.G.; NASCIMENTO, I.R. Reação de genótipos de batata-doce a nematoides de galhas em condições de temperatura elevada. Bioscience Journal, Uberlândia, v.29, n.6, p.1869-1877, 2013. Available from: http://www.seer.ufu.br/index.php/biosciencejournal/article/view/22099. Access on: 4 Apr. 2017.

CHITWOOD, B.G. Root-Knot Nematodes - Part I. A revision of the genus Meloidogyne Goeldi, 1887. Proceedings of the Entomological Society of Washington, Washington, v.16, n.2, p.90-104, 1949.

DALLEMOLE-GIARETTA, R.; FREITAS, L.G.; FERRAZ, S.; NEVES, W. S.; LOPES, E. A.; COUTINHO, M. M. Effect of different rates of Pochonia chlamydosporia var. chlamydosporia chlamydospores on Meloidogyne javanica control. Nematologia Brasileira, Piracicaba, v.32, n.4, p.327-332, 2008.

FERRAZ, L.C.C.B.; BROWN, D.J.F. O manejo integrado de nematoides. In: Nematologia de plantas: fundamentos e importância. Manaus: Norma Editora, 2016. chap.10, p.182-233.

FERRAZ, L.C.C.B. Nematoides. In: AMORIM, L.; REZENDE, J.A.M.; BERGAMIN FILHO, A. Manual de Fitopatologia: princípios e conceitos. Ouro Fino: Agronômica Ceres, 2018. chap.13, p.195-211.

FERRAZ, L.C.C.B. Reações de genótipos de soja a Pratylenchus brachyurus. Nematologia Brasileira, Piracicaba, v.20, n.1, p.22-31, 1996.

FERRAZ, S.; FREITAS, L.G.; LOPES, E.A.; DIAS-ARIEIRA, C. Solarização e biofumigação. In: Manejo sustentável de fitonematoides. Viçosa: UFV, 2010. chap.11, p.86-100.

FERRAZ, S.; SANTOS, M.A. Controle biológico de fitonematóides pelo uso de fungos. Revisão Anual de Patologia de Plantas, Brasília, v.3, p.283-314, 1995.

FERREIRA, D.F. Sisvar: a computer statistical analysis system. Ciência e Agrotecnologia, Lavras, v.35, n.6, p.1039-1042, 2011. https://doi. org/10.1590/S1413-70542011000600001 
JENKINS, W.R. A rapid centrifugal-flotation technique for separating nematodes from soil. Plant Disease Reporter, Washington, v.48, p.691-692, 1964. Available from: https://www.cabdirect.org/cabdirect/abstract/19650801105. Access on: 10 Oct. 2018.

LIU, X.; XIANG, M.; CHE, Y. The living strategy of nematophagous fungi. Mycoscience, Ishikawa, v.50, n.1, p.20-25, 2009. https://doi. org/10.1007/S10267-008-0451-3

LOPES, E.A.; FERRAZ, S.; FERREIRA, P.A.; FREITAS, L.G.; DHINGRA, O.D.; GARDIANO, C.G.; CARVALHO, S.L. Potencial de isolados de fungos nematófagos no controle de Meloidogyne javanica. Nematologia Brasileira, Piracicaba, v.31, n.2, p.20-26, 2007.

LUBIAN, C.; MARTINHA, D.D.; PORTZ, R.L.; SILVA FILHO, A.G.S.; CORTEZ, V.G.; MISSIO, V.C. Daily Indexes for predation and growth of nematophagous mushrooms Species of Hohenbuehelia (Pleurotaceae) on Panagrellus redividus. Journal of Agricultural Science, Richmond Hill, v.10, n.3, p.276-289, 2018. https://doi.org/10.5539/jas.v10n3p276

MACHADO, A.C.Z. Current nematode threats to Brazilian agriculture. Current Agricultural Science and Technology, Pelotas, v.20, n.1, p.26-35, 2014. Available from: https://periodicos.ufpel.edu.br/ojs2/index.php/CAST/article/view/3737. Access on: 17 Oct. 2017.

MACHADO, J.C.; VIEIRA, B.S.; LOPES, E.A.; CANEDO, E.J. Controle de Meloidogyne javanica com Pochonia chlamydosporia e esterco bovino. Bioscience Journal, Uberlândia, v.29, n.3, p.590-596, 2013. Available from: http://www.seer.ufu.br/index.php/biosciencejournal/ article/view/14044. Access on: 3 Oct. 2018.

MARINO, R.H.; SILVA, D.G.C. Controle do nematoide das galhas por Pleurotus ostreatus em alface. Scientia Plena, Sergipe, v.9, n.10, p.1-6, 2013. Available from: https://www.scientiaplena.org.br/sp/article/view/1059. Access on: 28 Aug. 2017.

MORANDI, M.A.B.; BETTIOL, W. Controle biológico de doenças de plantas no Brasil. In: BETTIOL, W.; MORANDI, M.A.B. (ed). Biocontrole de doenças de plantas: uso e perspectivas. Jaguariúna: Embrapa Meio Ambiente, 2009. chap.1, p.7-14.

MORGAN-JONES, G.; RODRÍGUEZ-KÁBANA, R. Perspective: Phytonematode Pathology: Fungal Modes of Action. A Perspective. Nematropica, Florida, v.15, n.1, p.107-114, 1985.

NUNES, H.T.; MONTEIRO, A.C.; POMELA, A.W.V. Uso de agentes microbianos e químico para o controle de Meloidogyne incognita em soja. Acta Scientiarum. Agronomy, Maringá, v.32, n.3, p.403-409, 2010. https://doi.org/10.4025/actasciagron.v32i3.2166

PINHEIRO, J.B.; REIFSCHNEIDER, F.J.B.; PEREIRA, R.B.; MOITA, A.W. Reprodução de Meloidogyne spp. em Capsicum spp. Nematologia Brasileira, Piracicaba, v.37, n.1-2, p.20-25, 2013. Available from: https://www.alice.cnptia.embrapa.br/alice/bitstream/doc/978486/1/ NB2025.pdf. Access on: 25 Jul. 2017.

PIRES, D.; COSTA, S.; MOURÃO, I.; ALMEIDA, M.T. Avaliação da resistência de cultivares de feijoeiro (Phaseolus spp.) a Meloidogyne javanica, para uso como porta-enxerto. Actas Portuguesas de Horticultura, Lisboa, n.25, p.126-132, 2016. Available from: https:// repositorium.sdum.uminho.pt/bitstream/1822/51977/3/Pires\%20APH\%202016.pdf. Access on: 3 Aug. 2017.

PUTZKE, M.T.L.; MATSUMURA, A.T.S.; CAVALCANTI, M.A.Q.; CARGNELUTTI FILHO, A. Taxonomia e importância das espécies de Hohenbuehelia, Resupinatus e Pleurotus no controle de Meloidogyne javanica. Caderno de Pesquisa, Série Biologia (UNISC), Santa Cruz do Sul, v.19, n.3, p.38-81, 2007.

ROSA, J.M.O.; WESTERICH, J.N.; WILCKEN, S.R.S. Reprodução de Meloidogyne javanica em olerícolas e em plantas utilizadas na adubação verde. Tropical Plant Pathology, Brasília, v.38, n.2, p.133-141, 2013. https://doi.org/10.1590/S1982-56762013000200007

SANTIN, R.C.M. Potencial do uso dos fungos Trichoderma spp. e Paecilomyces lilacinus no biocontrole de Meloidogyne incognita em Phaseolus vulgaris. 2008. 91f. Thesis (Doctorate in Phytotechny) - Universidade Federal do Rio Grande do Sul, Porto Alegre, 2008. Available from: https://www.lume.ufrgs.br/bitstream/handle/10183/15383/000677405.pdf?sequence=1\&isAllowed=y. Access on: 26 Jul. 2017.

SANTOS, H.G.; JACOMINE, P.K.T.; ANJOS, L.H.C.; OLIVEIRA, V.A.; LUMBRERAS, J.F.; COELHO, M.R.; ALMEIDA, J.A.; ARAUJO FILHO, J.C.; OLIVEIRA, J.B.; CUNHA, T.J.F. Sistema Brasileiro de Classificação de Solos. Brasília: Embrapa Solos, 2018.

SHARON, E.; BAR-EYAL, M.; CHET, I.; HERRERA-ESTRELLA, A.; KLEIFELD, O.; SPIEGEL, Y. Biological control of the root-knot nematode Meloidogyne javanica by Trichoderma harzianum. Phytopathology, Saint Paul, v. 91, n. 7, p. 687-693, 2001. https://doi.org/10.1094/ PHYTO.2001.91.7.687 
SZABÓ, M.; CSEPREGI, K.; GÁLBER, M.; VIRÁNYI, F.; FEKETE, C. Control plant-parasitic nematodes with Trichoderma species and nematode-trapping fungi: The role of chi18-5 and chi18-12 genes in nematode egg-parasitism. Biological Control, Orlando, v. 63, n. 2, p. 121-128, 2012. https://doi.org/10.1016/j.biocontrol.2012.06.013

THORN, R.G.; BARRON, G.L. Carnivorous Mushrooms. Science, Washington, v.224, n.4644, p.76-78, 1984. https://doi.org/10.1126/ science.224.4644.76

THORN, R.G.; BARRON, G.L. Nematoctonus and the tribe Resupinateae in Ontario, Canada. Mycotaxon, Ithaca, v.25, n.2, p.321-453, 1986.

VIGGIANO, J.R.; FREITAS, L.G.; LOPES, E.A. Use of Pochonia chlamydosporia to control Meloidogyne javanica in cucumber. Biological Control, Sophia Antipolis, v.69, p.72-77, 2014. https://doi.org/10.1016/j.biocontrol.2013.11.004

VINALE, F.; SIVASITHAMPARAM, K.; GHISALBERTI, E.L.; MARRA, R.; WOO, S.L.; LORITO, M. Trichoderma-plant-pathogen interactions. Soil Biology and Biochemistry, Nottingham, v.40, n.1, p.1-10, 2008. https://doi.org/10.1016/j.soilbio.2007.07.002 